\title{
The effect of dietary forage to concentrate ratio and forage type on milk fatty acid composition and milk fat globule size of lactating cows
}

\author{
Mari J. Jaakamo,, ${ }^{1}$ Tytti J. Luukkonen, ${ }^{1}$ Piia K. Kairenius, ${ }^{1}$ Ali R. Bayat, ${ }^{1}$ Seppo A. Ahvenjärvi, ${ }^{1}$ \\ Tuomo M. Tupasela, ${ }^{2}$ Johanna H. Vilkki, ${ }^{3}$ Kevin J. Shingfield, ${ }^{*}$ and Heidi M. Leskinen ${ }^{1} \dagger$ \\ ${ }^{1}$ Milk Production, Production Systems Natural Resources Institute Finland (Luke), FI-31600 Jokioinen, Finland \\ ${ }^{2}$ Food Processing and Quality, Production Systems Natural Resources Institute Finland (Luke), Fl-31600 Jokioinen, Finland \\ ${ }^{3}$ Animal Genetics, Production Systems, Natural Resources Institute Finland (Luke), FI-31600 Jokioinen, Finland
}

\section{ABSTRACT}

We examined the effects of 2 grass silage-based diets differing in forage:concentrate (FC) ratio and those of a red clover silage-based diet on intake, milk production, ruminal fatty acid (FA) biohydrogenation, milk FA composition, and milk fat globule (MFG) size distribution. Ten multiparous Nordic Red cows received the following treatments: grass silage-based diets containing high $(70: 30, \mathrm{HG})$ or low $(30: 70, \mathrm{LG}) \mathrm{FC}$ ratio or a red clover silage-based diet with an $\mathrm{FC}$ ratio of 50:50 (RC) on a dry matter basis. Determinations of MFG were performed from fresh milk samples without addition of EDTA so the results of fat globules $>1 \mu \mathrm{m}$ in diameter are emphasized instead of the entire globule population. Lower FC ratio in grass silage-based diets increased milk production with no effect on daily fat yield, leading to $13 \%$ lower milk fat concentration. The effect of FC ratio on MFG size was moderate. It did not affect the volume-weighted diameter in grass silagebased diets, although LG lowered the volume-surface diameter of MFG in the size class $>1 \mu \mathrm{m}$ compared with HG. Compared with HG, feeding LG moderately decreased the biohydrogenation of $18: 2 n-6$, leading to a higher level of polyunsaturated fatty acids in milk fat. Feeding RC lowered milk fat concentration and daily milk fat yield compared with grass silage-based diets. The volume-weighted diameter of MFG in the size class $>1 \mu \mathrm{m}$ was smaller in RC milk compared with grass silage-based diets. Feeding RC increased the flow of $18: 3 \mathrm{n}-3$ at the omasum by 2.4 -fold and decreased the apparent ruminal 18:3n-3 biohydrogenation compared with grass silage-based diets despite similar intake of 18:3n-3. It also resulted in the lowest amount of saturated FA and the highest amounts of cis-9 18:1, 18:3n-

Received October 11, 2018.

Accepted June 17, 2019.

* Deceased.

$\dagger$ Corresponding author: heidi.leskinen@luke.fi
3, and polyunsaturated FA in milk. In conclusion, LG decreased milk fat content and induced minor changes in MFG size distribution compared with HG, whereas RC lowered milk fat production, altered milk FA composition to nutritionally more beneficial direction, and led to smaller MFG compared with grass silage-based diets.

Key words: milk fat globule, fatty acid composition, grass silage, red clover silage, dairy cow

\section{INTRODUCTION}

Milk fat is secreted as fat globules surrounded by a trilayer membrane, the milk fat globule membrane (MFGM), which consists of polar lipids (PL), proteins, cholesterol, and various minor components (Heid and Keenan, 2005; Lopez et al., 2008). Polar lipids in milk have been proposed to have anticholesterolemic and anticarcinogenic effects and to support probiotic activity (Spitsberg, 2005; Dewettinck et al., 2008; Jiménez-Flores and Brisson, 2008). In addition, MFGM has been shown to improve cognitive function of formulafed infants (Timby et al., 2014). Furthermore, milk fat globule (MFG) size affects fatty acid (FA) digestion and bioavailability (Garcia et al., 2014; Singh and Gallier, 2017) as well as the physico-chemical and functional properties of dairy products (Edén et al., 2016; Logan et al., 2017). The accumulating evidence on the potential health benefits of MFGM components and functional properties of MFG has increased interest in studying the effect of dairy cow nutrition on MFG size and membrane composition.

Microlipid droplets fuse into larger droplets in the cytoplasm of mammary secretory cells before being enveloped by a bilayer that originates from the apical plasma membrane and then being released to the lumen (Masedunskas et al., 2017; Cohen et al., 2018). Small MFG contain relatively more membrane material than larger MFG, but the regulation of lipid droplet formation remains unclear (Heid and Keenan, 2005; 
Mesilati-Stahy et al., 2015). Positive correlations have been shown between MFG size, daily fat yield, and fat: protein ratio (Wiking et al., 2004, 2010; Couvreur and Hurtaud, 2017). Furthermore, FA composition varies between MFG of different sizes (Couvreur et al., 2007; Mesilati-Stahy et al., 2011; Lu et al., 2016). Smaller MFG contain higher levels of PUFA and very-long-chain FA due to the higher content of PL (Lopez et al., 2008; Mesilati-Stahy et al., 2011). Therefore, the mechanisms of MFG formation also partly define milk fat composition and thus affect the nutritional and technological properties of milk (Argov-Argaman et al., 2014).

Diet composition of dairy cows has been postulated to affect MFG size (Lopez et al., 2008; Wiking et al., 2010; Argov-Argaman et al., 2014). However, investigations of the effects of dairy cow diet on MFG size and composition have yielded inconclusive results. Some studies reported that diets increasing the PUFA levels in milk, such as pasture (Couvreur et al., 2007) or oil supplements (Lopez et al., 2008), led to a decrease or no change in MFG size (Wiking et al., 2010), whereas Argov-Argaman et al. (2014) found a trend of increasing MFG size when a diet based on corn silage, oat hay, and clover hay with a forage:concentrate $(\mathbf{F C})$ ratio of 65:35 versus 35:65 was fed to cows.

Red clover is well known to increase PUFA, especially 18:3n-3, and to lower SFA concentrations in milk fat (Dewhurst et al., 2006; Vanhatalo et al., 2007; Halmemies-Beauchet-Filleau et al., 2014). The mechanisms governing the high PUFA level in milk of cows fed red clover silage are still not well defined, although high polyphenol oxidase activity, decreased lipolysis in the rumen, and changes in digestion kinetics, feed particle size, and rumen bacterial composition leading to higher ruminal escape of PUFA have been postulated (Halmemies-Beauchet-Filleau et al., 2013). However, published data on how grass silage-based diets, the predominant feeding system in Nordic countries, and red clover-based diet affect MFG are scarce (Couvreur et al., 2006; Wiking et al., 2010).

The experimental setup and treatments were originally formulated to induce varying effects on enteric methane production, nutrient digestion (Bayat et al., 2017), and rumen microbiome (Tapio et al., 2018) in 5 high- and 5 low-methane-emitting cows, with the main goal of understanding the mechanisms underlying the effects. However, the results were expanded to include milk fat quality and MFG as reported herein, independent of the methane-emitting potential of the cows. Our aim was to investigate how FC ratio in grass silagebased diets and a diet based on red clover silage affects MFG size distribution, milk FA composition, and FA biohydrogenation in the rumen. We hypothesized that the high proportion of concentrate in grass silage-based dairy cow diets would decrease MFG size compared with a high-forage diet. In addition, we hypothesized that the reduced biohydrogenation of long-chain PUFA in the rumen in the red clover silage-based diet would increase the content of long-chain PUFA of milk fat and thus reduce MFG size compared with grass silage-based diets.

\section{MATERIALS AND METHODS}

\section{Animals, Experimental Design, and Diets}

Experimental procedures were approved by the National Animal Ethics Committee (ESAVI/5344/04.10.07/2014, Finland) in accordance with the guidelines of protection of animals used for experimental and other scientific purposes according to European Council 86/609/EEC (European Council, 1986). Ten multiparous Finnish Nordic Red cows fitted with rumen cannula (i.d. $100 \mathrm{~mm}$; Bar Diamond Inc., Parma, ID) of (mean \pm SD) $682 \pm 71.1 \mathrm{~kg}$ live weight, $4.2 \pm 0.6$ parity, and $74.4 \pm 21.0 \mathrm{~d}$ postpartum and producing $41.5 \pm 4.4 \mathrm{~kg}$ milk/d were randomly allocated to experimental diets in a 3 times replicated $3 \times 3$ Latin square with an extra replicate that was randomly allocated to one of the diets in each $35-\mathrm{d}$ experimental period, resulting in $\mathrm{n}=10$ for each diet throughout the study. The experiment was split into 2 blocks (blocks A and B) of 4 or 6 cows over time (7-wk interval) to have all cows in the same lactation stage.

Cows were offered grass silage (timothy-meadow fescue sward) and cereal-based concentrate diets with either 70:30 (high grass silage, $\mathbf{H G ) ~ o r ~ 3 0 : 7 0 ~ ( l o w ~ g r a s s ~}$ silage, LG) FC ratio (on a DM basis) and a red clover silage and cereal-based concentrate diet (RC) with 50:50 FC ratio. All diets were offered as TMR. Silages were prepared from mixed timothy (Phleum pratense) and meadow fescue (Festuca pratensis) and from red clover (Trifolium pratense) swards treated with $5 \mathrm{~L} / \mathrm{t}$ of formic acid-based additive (760 $\mathrm{g}$ of formic acid and $55 \mathrm{~g}$ of ammonium formate, AIV 2 Plus, Kemira Ltd., Helsinki, Finland). Formulation of experimental treatments and chemical compositions of experimental feeds are shown in Table 1. Diets were offered as equal meals ad libitum 4 times a day at 0600, 0900, 1600, and 1900 h. Cows were milked twice a day at 0700 and $1645 \mathrm{~h}$.

\section{Sampling and Chemical Analyses}

Feed intake and feed refusals were measured daily. Representative samples of grass silage, red clover silage, and dietary concentrates were collected during TMR preparation daily over $5 \mathrm{~d}$ on d 30 to 34 of each experimental period for analysis of chemical composition 
Table 1. Formulation of experimental diets and chemical composition of feeds

\begin{tabular}{|c|c|c|c|}
\hline \multirow[b]{2}{*}{ Item } & \multicolumn{3}{|c|}{ Treatment $^{1}$} \\
\hline & $\mathrm{HG}$ & LG & $\mathrm{RC}$ \\
\hline \multicolumn{4}{|l|}{ Ingredient, $\%$ on DM basis } \\
\hline Grass silage & 70 & 30 & - \\
\hline Red clover silage & - & - & 50 \\
\hline Barley & 13.8 & 32.1 & 22.9 \\
\hline Molassed sugar beet pulp & 6.96 & 16.2 & 11.6 \\
\hline Rapeseed meal & 8.58 & 20.0 & 14.3 \\
\hline Vitamin and mineral premix ${ }^{2}$ & 0.69 & 1.61 & 1.15 \\
\hline \multicolumn{4}{|l|}{ Composition, $\mathrm{g} / \mathrm{kg}$ of $\mathrm{DM}$} \\
\hline $\mathrm{DM}$ & 262 & 230 & 891 \\
\hline $\mathrm{OM}$ & 927 & 898 & 921 \\
\hline $\mathrm{CP}$ & 129 & 179 & 180 \\
\hline Ether extract & 38.4 & 45.2 & 31.9 \\
\hline NDF & 425 & 404 & 245 \\
\hline $\mathrm{ADF}$ & 252 & 281 & 136 \\
\hline Starch & 5.83 & 9.06 & 273 \\
\hline Water-soluble carbohydrates & 37.4 & 11.6 & 65.2 \\
\hline Gross energy, MJ/kg & 17.6 & 17.5 & 18.1 \\
\hline \multicolumn{4}{|l|}{ Fatty acid, mg/g of DM } \\
\hline 16:0 & 2.15 & 2.60 & 2.68 \\
\hline $18: 0$ & 0.17 & 0.47 & 0.19 \\
\hline cis-9 18:1 & 0.67 & 0.76 & 4.37 \\
\hline cis-11 18:1 & 0.11 & 0.15 & 1.06 \\
\hline cis-9,cis-12 18:2 (18:2n-6) & 3.04 & 3.66 & 7.16 \\
\hline cis-11 20:1 & 0.017 & 0.373 & 0.102 \\
\hline cis-9,cis-12,cis-15 18:3 (18:3n-3) & 7.32 & 7.65 & 1.21 \\
\hline$\Sigma$ SFA & 3.30 & 3.98 & 3.17 \\
\hline$\Sigma$ MUFA & 1.21 & 1.73 & 5.74 \\
\hline$\Sigma$ PUFA & 10.4 & 11.4 & 8.45 \\
\hline$\Sigma$ Fatty acids & 14.9 & 17.1 & 17.4 \\
\hline
\end{tabular}

${ }^{1}$ Refers to grass silage diets with forage:concentrate (FC) ratio 70:30 (HG) and 30:70 (LG), and red clover silage-based diet (RC) with FC ratio 50:50.

${ }^{2}$ Premix (Mahti-Mira, Vilomox Finland, Paimio) declared as containing (\%) Ca (22), Na (10.5), and Mg (6.4) and $(\mathrm{mg} / \mathrm{kg})$ vitamins $\mathrm{A}(156), \mathrm{D}(52), \mathrm{E}(1,144), \mathrm{CuSO}_{4}(1,180), \mathrm{MnSO}_{4}(1,025), \mathrm{ZnO}(2,127), \mathrm{Ca}\left(\mathrm{IO}_{3}\right)_{2}(66)$, $\mathrm{Na}_{2} \mathrm{SeO}_{3}(33)$, Se (37), and $\mathrm{CoCO}_{3}(520)$.

(Shingfield et al., 2002). Freeze-dried silage samples and air-dried concentrate samples were stored at $-80^{\circ} \mathrm{C}$ before FA analyses.

Spot samples $(500 \mathrm{~mL})$ of digesta entering the omasal canal were collected 3 times daily at 4 -h intervals from d 31 to 34 to determine the digesta flow from rumen to omasal canal, using indigestible NDF, chromium EDTA, and ytterbium acetate as markers as reported elsewhere (Ahvenjärvi et al., 2000). Sampling started at $0900 \mathrm{~h}$ and was advanced $1 \mathrm{~h}$ each day to cover a $12-\mathrm{h}$ period that was considered representative of the entire feeding cycle. Samples were separated to large particle, small particle, and liquid phases, and then freeze-dried and composited for FA analyses after mathematical reconstruction according to the triple marker method of Ahvenjärvi et al. (2000). Reconstituted samples were stored at $-80^{\circ} \mathrm{C}$.

Milk yield of each cow was recorded daily. Milk samples were collected from 8 consecutive milkings on d 28 to 32 and treated with preservative (Bronopol, Valio
Ltd., Helsinki, Finland) before analyses of milk composition (MilkoScan FT6000, Foss Electric, Hillerød, Denmark). Untreated milk samples of 4 consecutive milkings on d 30 to 32 were collected, stored at $-20^{\circ} \mathrm{C}$, and combined according to milk yield for FA analyses. Additional unpreserved milk samples of 2 consecutive milkings were collected on d 33 to 34 during block B, stored at $4^{\circ} \mathrm{C}$, and analyzed for MFG size distribution on the following day.

\section{Milk Fat Globule Size Distribution Measurements}

Size distributions of MFG from fresh milk samples (n $=6$ per treatment) were determined using a Mastersizer 2000 (Malvern Panalytical Ltd., Malvern, UK) particle size analyzer based on laser light scattering. The particle refractive index was 1.458 for milk fat and 1.330 for water, and the beam wavelengths used were $633 \mathrm{~nm}$ (red light) and $466 \mathrm{~nm}$ (blue light). Milk samples were directly introduced to the Mastersizer measurement cell 
to reach laser obscuration of 5 to $10 \%(6.79 \% \pm 0.64)$. Each milk sample was measured 4 times, and standard parameters as defined in Lopez et al. (2008) were calculated by the software as follows: mean volume-weighted diameter $\left(d_{4,3}\right)$, mean volume-surface diameter $\left(d_{3,2}\right)$, mode as the peak of the frequency distribution, specific surface area, and size distribution width. The results of MFG measurements were divided to $<1-\mu \mathrm{m}$ and $>1$ $\mu \mathrm{m}$ classes because casein micelles contributing to the $<1-\mu \mathrm{m}$ class were not disrupted from the fresh milk samples. Further calculations were conducted only for the $>1-\mu \mathrm{m}$ size class.

\section{Lipid Analysis}

Fatty acid methyl esters of milk and feed samples were prepared according to Shingfield et al. (2003). Briefly, milk fat was extracted twice from $1 \mathrm{~mL}$ of milk with a mixture of ammonia, ethanol, diethyl ether, and hexane $(0.2: 1: 2.5: 2.5, \mathrm{vol} / \mathrm{vol})$, and it was then methylated by transesterification with methanolic sodium methoxide in the presence of methyl acetate. Fatty acid methyl esters from feed samples were prepared in a single extraction-methylation step with chloroform and methanolic sulfuric acid (2\%, vol/vol). Total lipids of omasum digesta samples were extracted with a hexane: isopropanol $(3: 2, \mathrm{vol} / \mathrm{vol})$ mixture and methylated in 2 sequential procedures with methanolic sodium methoxide and sulfuric acid in methanol (1\%, vol/vol) (Halmemies-Beauchet-Filleau et al., 2013). Tritridecanoin (T135, NuChek Prep Inc., Elysian, MN) and tridecanoic acid (N-13A, NuChek Prep Inc.) were used as internal standards in calculating the fatty acid content in feed and omasal digesta samples, respectively.

Profiles of FAME for milk, feed, and omasal digesta samples were determined by GC coupled with flameionization detector (6890N, Agilent Technologies, Santa Clara, CA) equipped with a CP-Sil 88 column $(100 \mathrm{~m}$ $\times 0.25 \mathrm{~mm}$ i.d., $0.2-\mu \mathrm{m}$ film thickness; Agilent Technologies). The FAME were separated using a temperature gradient program with injector and detector temperatures maintained at $255^{\circ} \mathrm{C}$ (Shingfield et al., 2003). Hydrogen was used as a carrier gas starting from 206.8 $\mathrm{kPa}$ initial pressure and gradually raised after $50 \mathrm{~min}$ to a final pressure of $310.3 \mathrm{kPa}$. Isomers of $18: 1$ were separated in an isothermal run at constant $0.9 \mathrm{~mL} / \mathrm{min}$ carrier gas flow and oven temperature at $170^{\circ} \mathrm{C}$. Dimethyl acetals (DMA) of omasal digesta samples were determined under same conditions as FAME (Ventto et al., 2017). Conjugated linoleic acid composition in milk and omasal digesta samples was determined with HPLC equipped with photodiode array detector (Acquity UPLC System, Waters Ltd., Milford, MA) and 4 silver-impregnated HPLC silica columns (ChromSpher
5 Lipids, $250 \times 4.6 \mathrm{~mm}$ i.d., $5-\mu \mathrm{m}$ particle size; Varian Ltd., Walton-on-Thames, UK). Acetonitrile in heptane $(0.1 \%, \mathrm{vol} / \mathrm{vol})$ was used as the mobile phase with a constant flow of $1 \mathrm{~mL} / \mathrm{min}$, oven temperature was $22^{\circ} \mathrm{C}$, and CLA isomers were detected at $233 \mathrm{~nm}$ according to Halmemies-Beauchet-Filleau et al. (2011). Methyl esters of FA and CLA were identified by comparing sample peak retention times to the corresponding peak retention times of analytical standard mixtures run in the same sample set or by analyzing 4,4-dimethyloxazoline derivatives of FAME on GC-MS (5973N, Agilent Technologies, Wilmington, DE) (Halmemies-BeauchetFilleau et al., 2011). The amount of specific CLA isomers in milk fat and omasal digesta samples was determined based on proportionate peak area responses of trans7,cis-9 CLA, trans-8,cis-10 CLA and cis-9,trans-11 CLA analyzed by HPLC-photodiode array detector and the weight percentage of corresponding peak acquired by GC-flame-ionization detection (Shingfield et al., 2003). Fatty acid content was determined as grams per $100 \mathrm{~g}$ of total FA, using theoretical relative response factors (Halmemies-Beauchet-Filleau et al., 2011).

\section{Statistical Analysis}

All statistical analyses of data were performed by ANOVA, using SAS (version 9.4; SAS Institute Inc., Cary, NC). Milk FA composition, FA flow at the omasum, milk production, and feed intake data were analyzed with PROC GLIMMIX model, including the fixed effects of period, diet, and diet by period interaction and cow, block, and period by block interaction as random effects. The experiment was split into 2 blocks of 4 or 6 cows over time to have all cows at the same lactation stage. Model was $\mathrm{Y}_{\mathrm{ijkl}}=\mu+\mathrm{A}_{\mathrm{i}}+\mathrm{P}_{\mathrm{j}}+\mathrm{D}_{\mathrm{k}}+$ $\mathrm{B}_{1}+\mathrm{P}_{\mathrm{j}} \times \mathrm{D}_{\mathrm{k}}+\mathrm{P}_{\mathrm{j}} \times \mathrm{B}_{\mathrm{l}}+\varepsilon_{\mathrm{ijk} \mathrm{kl}}$, where $\mathrm{Y}_{\mathrm{ijkl}}$ represents the dependent variable; $\mu$, the overall mean; $\mathrm{A}$, the random effect of animal ( $\mathrm{i}=1$ to 10 ); $\mathrm{P}$, the fixed effect of period ( $\mathrm{j}=1$ to 3$) ; \mathrm{D}$, the fixed effect of $\operatorname{diet}(\mathrm{k}=1$ to $3) ; \mathrm{B}$, the random effect of block $(1=1$ and 2$) ; \mathrm{P}_{\mathrm{j}} \times \mathrm{D}_{\mathrm{k}}$, the fixed effect of period and diet; $\mathrm{P}_{\mathrm{j}} \times \mathrm{B}_{\mathrm{l}}$, the random effect of period and block; and $\varepsilon_{\mathrm{ijkl}}$ the residual error. Data on MFG size distribution were analyzed with PROC GLIMMIX model with the same fixed effects as above and including cow as a random effect (block and period $\times$ block interaction excluded). Orthogonal contrasts were (1) LG vs. HG (FC effect in grass silagebased diets) and (2) RC vs. grass silage diets (forage type effect). The relationship between MFG size results (standard parameters of MFG in $>1-\mu \mathrm{m}$ size class) and milk fat yield was evaluated by linear regression analysis using PROC REG procedure of SAS. Least squares means \pm standard error of the means are reported. $P$-values $<0.05$ are considered significant, whereas $P$ - 
values between 0.05 and 0.10 indicate a trend toward significance.

\section{RESULTS}

\section{Intake and Milk Production}

Intakes of DM and gross energy in LG were 13 and $14 \%$ higher $(P<0.001)$ than in $\mathrm{HG}$, but $5 \%$ lower in $\mathrm{RC}(P<0.01)$ compared with the average intakes of grass silage-based diets (Table 2). Intakes of NDF and ADF were 8 and $13 \%$ lower in LG than HG $(P<$ $0.01)$, and $\mathrm{RC}$ had $6 \%$ lower $(P<0.01) \mathrm{NDF}$ intake than grass silage-based diets. Starch intake was 2.6-fold higher in LG than HG $(P<0.001)$. Total FA intake was increased by $19 \%$ in LG $(P<0.001)$ compared with HG, with no difference between grass silage-based diets and RC. Intake of MUFA was 1.9-fold higher ( $P$ $<0.001)$ in LG than in HG, and intake of cis-9 18:1 was 2.1 -fold higher $(P<0.001)$ in LG than in HG. Furthermore, SFA intake in LG was $10 \%$ higher $(P<0.01)$ than in HG and $6 \%$ higher $(P<0.05)$ in RC compared with grass silage diets, but PUFA intakes did not differ between treatments. Intake of 18:2n-6 was 1.6-fold higher $(P<0.001)$ in LG compared with HG, but it did not differ between RC and grass silage diets. Intake of cis-11 20:1 in RC was 4.1-fold higher $(P<0.001)$ than in grass silage-based diets. Intake of $18: 3 \mathrm{n}-3$ was $40 \%$ lower $(P<0.001)$ in LG compared with HG, but it did not differ between RC and grass silage diets.

Milk and lactose yields were both $15 \%$ higher $(P<$ 0.01) in LG than in HG, but milk yield did not differ

Table 2. Effects of forage:concentrate ratio in grass silage diets and forage type (red clover silage vs. grass silage) on feed intake of lactating cows $^{1}$

\begin{tabular}{|c|c|c|c|c|c|c|}
\hline \multirow[b]{2}{*}{ Item } & \multicolumn{3}{|c|}{ Treatment $^{2}$} & \multirow[b]{2}{*}{ SEM } & \multicolumn{2}{|c|}{ Contrast $(P \text {-value })^{3}$} \\
\hline & $\mathrm{HG}$ & LG & $\mathrm{RC}$ & & FC ratio & Forage type \\
\hline \multicolumn{7}{|l|}{ Intake, $\mathrm{kg} / \mathrm{d}$} \\
\hline Silage DM & 16.7 & 8.24 & 12.1 & 0.309 & $<0.001$ & 0.17 \\
\hline Concentrate DM & 6.7 & 18.3 & 11.6 & 0.352 & $<0.001$ & $<0.01$ \\
\hline Total DM & 23.4 & 26.5 & 23.7 & 0.62 & $<0.001$ & $<0.01$ \\
\hline $\mathrm{OM}$ & 21.7 & 24.4 & 21.6 & 0.57 & $<0.001$ & $<0.01$ \\
\hline $\mathrm{CP}$ & 3.37 & 4.37 & 4.25 & 0.103 & $<0.001$ & $<0.001$ \\
\hline Ether extract & 0.86 & 0.90 & 0.91 & 0.033 & 0.06 & 0.08 \\
\hline NDF & 8.6 & 7.95 & 7.77 & 0.221 & $<0.01$ & $<0.01$ \\
\hline $\mathrm{ADF}$ & 5.18 & 4.52 & 4.95 & 0.254 & $<0.001$ & 0.38 \\
\hline Starch & 1.93 & 5.05 & 3.26 & 0.099 & $<0.001$ & $<0.05$ \\
\hline Water-soluble carbohydrate & 1.09 & 1.50 & 0.89 & 0.035 & $<0.001$ & $<0.001$ \\
\hline Total gross energy intake, MJ/d & 416 & 476 & 423 & 11.4 & $<0.001$ & $<0.01$ \\
\hline \multicolumn{7}{|l|}{ Fatty acid, g/d } \\
\hline 14:0 & 1.17 & 1.07 & 0.89 & 0.039 & $<0.001$ & $<0.001$ \\
\hline $16: 0$ & 54.4 & 66.5 & 62.9 & 2.14 & $<0.001$ & 0.11 \\
\hline trans -3 16:1 & 4.45 & 2.02 & 3.45 & 0.289 & $<0.001$ & 0.23 \\
\hline cis-9 $16: 1$ & 1.56 & 1.78 & 1.82 & 0.084 & $<0.01$ & $<0.05$ \\
\hline $18: 0$ & 3.99 & 4.68 & 7.92 & 0.346 & $<0.01$ & $<0.001$ \\
\hline cis-9 18:1 & 41.0 & 84.5 & 60.4 & 5.34 & $<0.001$ & 0.27 \\
\hline cis-11 18:1 & 9.10 & 20.4 & 14.3 & 0.51 & $<0.001$ & 0.29 \\
\hline cis-9,cis-12 18:2 (18:2n-6) & 99.1 & 156.3 & 127.8 & 5.06 & $<0.001$ & 0.97 \\
\hline cis-9,cis-12,cis-15 18:3 (18:3n-3) & 131.1 & 79.4 & 108.4 & 4.81 & $<0.001$ & 0.28 \\
\hline $20: 0$ & 1.61 & 1.48 & 2.76 & 0.129 & 0.08 & $<0.001$ \\
\hline cis-11 20:1 & 0.96 & 1.94 & 5.92 & 0.188 & $<0.001$ & $<0.001$ \\
\hline cis-11, cis-14 20:2 (20:2n-6) & 0.28 & 0.40 & 0.99 & 0.030 & $<0.001$ & $<0.001$ \\
\hline $22: 0$ & 2.93 & 2.34 & 2.54 & 0.135 & $<0.001$ & 0.15 \\
\hline cis-13 22:1 & 0.48 & 0.73 & 0.84 & 0.032 & $<0.001$ & $<0.001$ \\
\hline $24: 0$ & 2.25 & 2.07 & 2.97 & 0.128 & $<0.05$ & $<0.001$ \\
\hline cis-15 24:1 & 0.80 & 0.91 & 0.63 & 0.033 & $<0.001$ & $<0.001$ \\
\hline $26: 0$ & 2.39 & 1.40 & 0.88 & 0.088 & $<0.001$ & $<0.001$ \\
\hline $28: 0$ & 3.66 & 1.85 & 1.07 & 0.122 & $<0.001$ & $<0.001$ \\
\hline $30: 0$ & 2.52 & 1.20 & 0.71 & 0.082 & $<0.001$ & $<0.001$ \\
\hline$\Sigma \mathrm{SFA}$ & 76.8 & 84.4 & 85.8 & 3.17 & $<0.01$ & $<0.05$ \\
\hline$\Sigma$ MUFA & 58.3 & 111.7 & 82.6 & 5.76 & $<0.001$ & 0.36 \\
\hline$\Sigma$ PUFA & 233 & 239 & 244 & 9.2 & 0.36 & 0.18 \\
\hline$\Sigma$ Fatty acids & 367 & 437 & 413 & 18.1 & $<0.001$ & 0.29 \\
\hline
\end{tabular}

${ }^{1}$ Values are LSM and pooled SEM, $\mathrm{n}=10$ for each treatment.

${ }^{2}$ Refers to grass silage diets with forage:concentrate (FC) ratio 70:30 (HG) and 30:70 (LG), and red clover silage-based diet (RC) with FC ratio $50: 50$.

${ }^{3} \mathrm{FC}$ ratio $=$ forage:concentrate ratio effect (30:70 vs. 70:30 in grass silage diets); forage type $=$ forage effect $($ red clover silage vs. grass silage). 
Table 3. Effects of forage:concentrate ratio in grass silage diets and forage type (red clover silage vs. grass silage) on milk production, milk composition, and milk fat globule size distribution

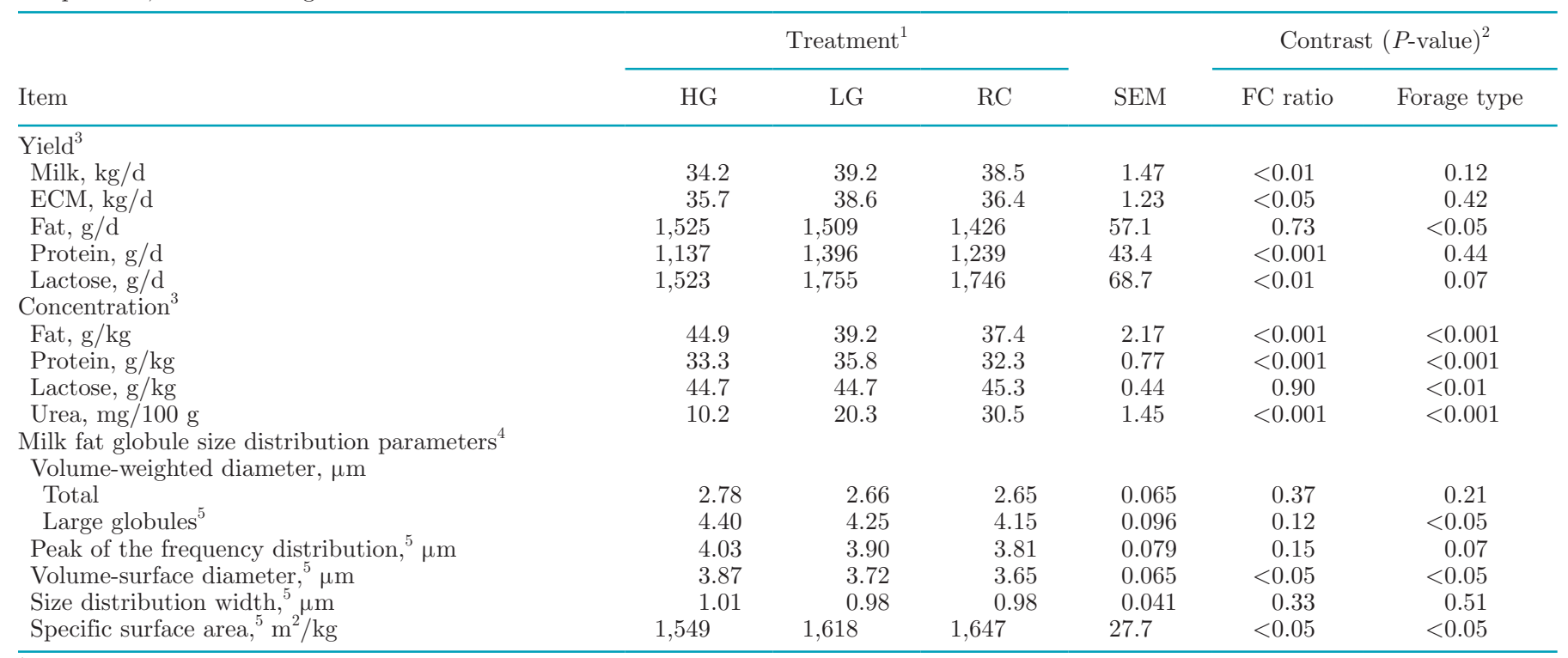

${ }^{1}$ Refers to grass silage diets with forage:concentrate (FC) ratio 70:30 (HG) and 30:70 (LG), and red clover silage-based diet (RC) with FC ratio 50:50.

${ }^{2} \mathrm{FC}$ ratio $=$ forage:concentrate ratio effect (30:70 vs. 70:30 in grass silage diets); forage type $=$ forage effect (red clover silage vs. grass silage)

${ }^{3}$ Values are LSM and pooled SEM, $\mathrm{n}=10$ for each treatment.

${ }^{4}$ Values are LSM and pooled SEM, $\mathrm{n}=6$ for each treatment.

${ }^{5}$ Fat globules more than $1 \mu \mathrm{m}$ in diameter.

between grass silage-based diets and RC (Table 3). The lactose concentration in milk was only $1 \%$ higher $(P<$ $0.01)$ and lactose yield tended to be higher $(P=0.07)$ in RC compared with grass silage-based diets. Furthermore, protein content and protein yield were 8 and $23 \%$ higher $(P<0.001)$ in LG compared with HG, whereas protein content was $7 \%$ lower $(P<0.001)$ in milk from $\mathrm{RC}$ compared with grass silage-based diets. Treatment RC increased $(P<0.001)$ the urea content by 2 -fold in milk compared with grass silage-based diets. However, the milk fat concentration was reduced $(P<0.001)$ by $13 \%$ in LG compared with $\mathrm{HG}$ and by $11 \%$ in RC compared with grass silage-based diets $(P<0.001)$, whereas milk fat yield was $6 \%$ lower $(P<0.05)$ in RC than in grass silage-based diets.

\section{Milk Fat Globule Size Distribution}

Distribution of MFG size in fresh milk produced with the 3 experimental treatments is illustrated in Supplemental Figure S1 (https://doi.org/10.3168/jds.2018 -15833). The overall volume-weighted mean diameter $\left(d_{4.3}\right)$ of fat globules did not differ between LG and HG or between RC and grass silage-based diets (Table 3). Data on MFG were further separated into 2 size classes, $<1 \mu \mathrm{m}$ and $>1 \mu \mathrm{m}$, because the MFG size distribution was bimodal and these 2 size ranges had distinct modes (data not shown). The RC diet produced MFG with $4 \%$ smaller $(P<0.05)$ globule sizes (volume-weighted diameter) compared with grass silage-based diets in the $>1-\mu \mathrm{m}$ size class. Volume-weighted diameter of the LG did not differ from that of the HG in the same $>1-\mu \mathrm{m}$ size class. A close to significant difference $(P=0.07)$ in the peak of the frequency distribution in the $>1-\mu \mathrm{m}$ size class was observed between grass silage-based diets and $\mathrm{RC}$. The size distribution widths in the $>1-\mu \mathrm{m}$ size class did not differ between diets. Specific surface area in the $>1-\mu \mathrm{m}$ size class was $4 \%$ greater $(P<0.05)$, both in LG compared with HG and in RC compared with grass silage-based diets $(P<0.05)$. The volumesurface diameter in the $>1-\mu \mathrm{m}$ size class was $4 \%$ lower $(P<0.05)$ both in LG compared with $\mathrm{HG}$ and in RC compared with grass silage-based diets $(P<0.05)$.

\section{Fatty Acid Flow at the Omasum}

Overall, 18:0 was the most abundant single FA accounting for 41 to $44 \%$ of total FA at the omasum, without significant differences between treatments (Table 4). Experimental treatments affected the flow of DMA at the omasum but did not affect DMA of 16:0, which accounted for 31 to $36 \%$ of total DMA (Supplemental Table S1; https://doi.org/10.3168/jds .2018-15833). 
Table 4. Effects of forage:concentrate ratio in grass silage diets and forage type (red clover silage vs. grass silage) on omasal fatty acid flow and ruminal biohydrogenation of unsaturated fatty acids of lactating cows ${ }^{1}$

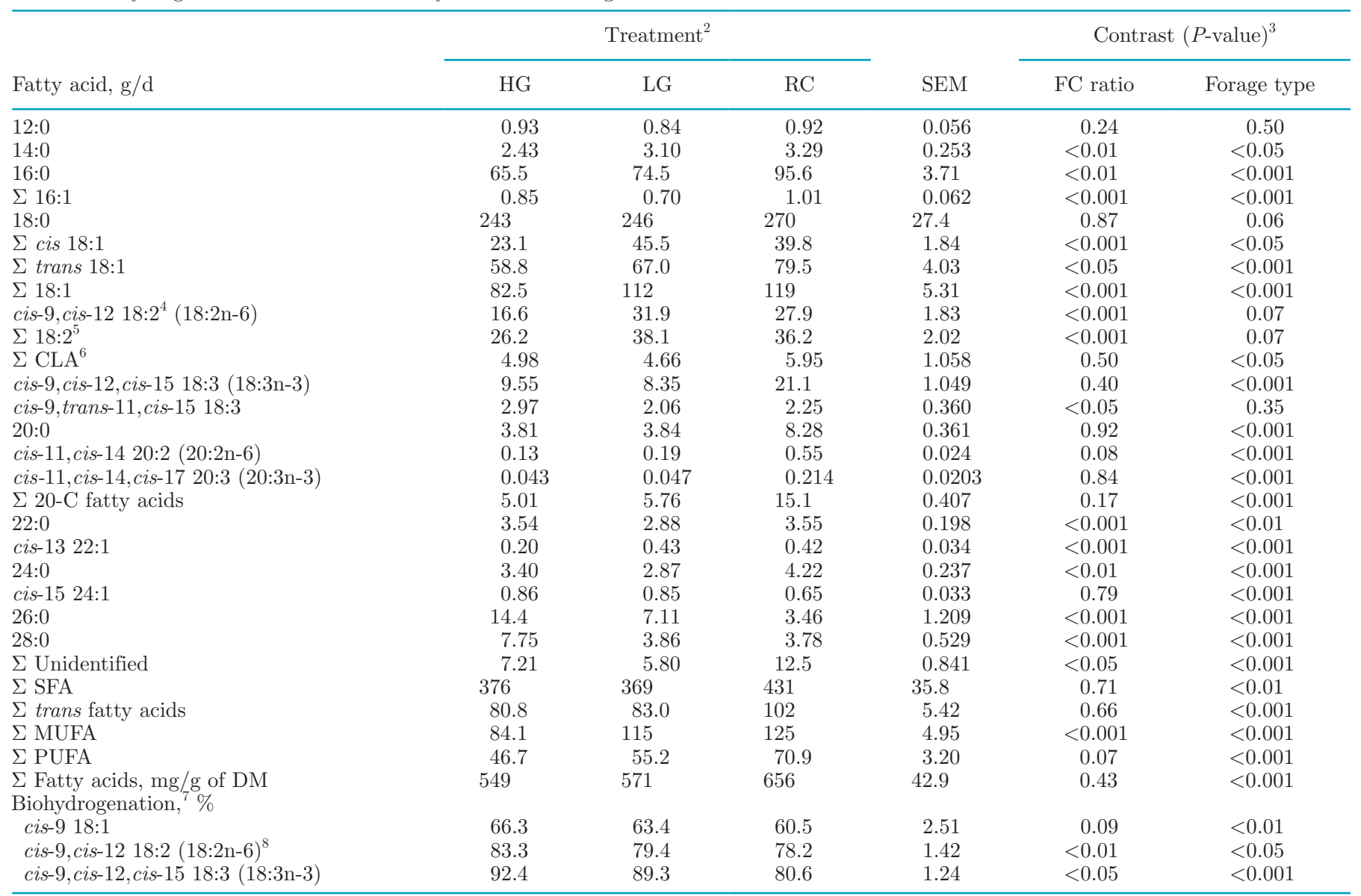

${ }^{1}$ Values are LSM and pooled SEM, $\mathrm{n}=10$ for each treatment. Values represent the mean over d 31 to 34.

${ }^{2}$ Refers to grass silage diets with forage:concentrate (FC) ratio 70:30 (HG) and 30:70 (LG), and red clover silage-based diet (RC) with ratio FC 50:50.

${ }^{3} \mathrm{FC}$ ratio $=$ forage:concentrate ratio effect (30:70 vs. 70:30 in grass silage diets); Forage type $=$ forage effect (red clover silage vs. grass silage)

${ }^{4}$ Co-elutes with cis-9, cis-15 18:2.

${ }^{5}$ Nonconjugated 18:2.

${ }^{6}$ Conjugated 18:2.

${ }^{7}[($ intake, g/d - flow at the omasum, g/d)/intake, g/d] $\times 100$.

${ }^{8}$ Co-elutes with cis-9,cis-15 18:2.

Forage:Concentrate Ratio. Dietary FC ratio in grass silage-based diets had no effect on total FA, SFA, trans FA, total CLA, 18:3n-3, 20:0, 20:3n-3, and total 20-carbon FA flow (Table 4), nor on the total amount of DMA (Supplemental Table S1). However, LG led to increases $(P<0.01)$ in omasal flow of $16: 0$, total 18:1, nonconjugated 18:2, cis-13 22:1, and MUFA, and decreases $(P<0.01)$ in the flow of total 16:1, cis9,trans-11,cis-15 18:3, anteiso 15:0, 22:0, 24:0, 26:0, and 28:0 compared with HG (Table 4, Supplemental Tables S2 and S3; https://doi.org/10.3168/jds.2018-15833). Trans-11 18:1 was the predominant 18:1 isomer in HG, whereas cis-9 18:1 accounted for $27 \%$ of total 18:1 in $\mathrm{LG}$, differing from HG $(P<0.001)$. The relative abun- dance of trans-10 18:1 was 2-fold higher $(P<0.001)$ in LG versus HG. Furthermore, flow of trans-10, cis-12 CLA was 5.5 -fold higher $(P<0.05)$ in LG versus HG (Supplemental Table S2). Flow of 18:2n-6 at the omasum was $92 \%$ higher in LG compared with HG and biohydrogenation of 18:2n-6 was the most complete in HG (Table 4). Feeding LG tended $(P=0.09)$ to decrease the biohydrogenation of cis-9 18:1 and decreased $(P<$ 0.05 ) biohydrogenation of 18:3n-3 compared with HG.

Forage Type. Feeding RC increased $(P<0.05)$ the flow of total FA, SFA, trans FA, total CLA, 18:3n-3, 20:0, 20:3n-3, and total 20-carbon FA flow (Table 4) compared with grass silage-based diets. The flow of trans-11 18:1 and cis-9,trans-11 CLA was more abun- 
dant $(P<0.05)$ in $\mathrm{RC}$ compared with grass silagebased diets (Supplemental Table S2). Red clover silage increased 18:3n-3 flow by 2.4-fold $(P<0.001)$ and decreased $(P<0.001)$ the apparent ruminal biohydrogenation of 18:3n-3 compared with grass silage-based diets (Table 4). Biohydrogenation of cis-9 18:1 and 18:2n- 6 was also lowered $(P<0.01$ and $P<0.05)$, but to a lesser extent than 18:3n-3.

\section{Milk Fatty Acid Composition}

Forage:Concentrate Ratio. The total amount of SFA in milk fat did not differ between HG and LG (Table 5). Low grass treatment increased $(P<0.001)$ the proportions of 10:0, 12:0, and 14:0 and decreased $(P$ $<0.001)$ 16:0 in milk fat compared with HG. Low grass treatment lowered $(P<0.01)$ the proportion of 18:0 in milk by $17 \%$ compared with HG diet. Furthermore, neither MUFA, total cis FA, nor total trans FA levels in milk fat were different between HG and LG, but LG led to $20 \%$ higher PUFA level $(P<0.001)$ compared with HG. Trans-10 18:1 content was $67 \%$ higher $(P<$ 0.001) in LG compared with HG (Table 6). Furthermore, 18:2n- 6 was $80 \%$ higher $(P<0.001)$ in $\mathrm{LG}$ versus HG, which also affected total cis 18:2 (Table 5). Total trans 18:2 was $26 \%$ lower $(P<0.001)$ in LG compared with HG. In addition, LG had the lowest $(P<0.001)$ proportion of CLA. Cis-9,trans-11 CLA accounted for 73 to $75 \%$ of total CLA and was the major CLA isomer in milk, followed by trans-7,cis-9 CLA and trans11,trans-13 CLA (Table 6). The ratio of n- $6 / \mathrm{n}-3$ FA was 1.86 -fold higher $(P<0.001)$ in LG than HG which was mainly affected by greater proportion of $18: 2 \mathrm{n}-6$ in LG milk.

Forage Type. Feeding RC decreased $(P<0.001)$ SFA in milk fat by $6 \%$ and lowered $(P<0.01)$ the proportions of 10:0, 12:0, 14:0, and 16:0 compared with grass silage-based diets (Table 5). The RC diet increased $16 \%$ MUFA and $22 \%$ PUFA levels $(P<0.001)$ compared with grass silage-based diets. The levels of both cis and trans FA were also elevated by 15 and $25 \%$ $(P<0.001)$ in $\mathrm{RC}$ relative to grass silage-based diets. Nevertheless, the sum of trans FA and SFA was $4 \%$ lower in $\mathrm{RC}(P<0.001)$ compared with grass silagebased diets. Furthermore, compared with grass silagebased diets, RC increased the sum of 18:1 isomers by $19 \%(P<0.001)$, especially the main $18: 1$ isomer cis-9 18:1. In addition, total trans 18:2 was $23 \%$ higher $(P<$ 0.001 ) and total CLA 34\% was higher in RC compared with grass silage-based diets.

The RC diet increased milk n-3 long-chain PUFA, such as 20:4n-3 and 20:5n-3, by $60 \%(P<0.001)$ and n-6 long-chain PUFA $20: 2 n-6$ by $32 \%$ compared with grass silage-based diets (Table 5). The proportion of 18:3n-3 in milk of cows fed RC was increased $(P<$ 0.001 ) by 1.7 -fold compared with grass silage treatments. The RC diet generally had a lower $(P<0.001)$ ratio of n- $6 / \mathrm{n}-3$ FA than grass silage treatments.

Detailed information on relative abundances of the isomers of 12:1, 14:1, 16:1, 20:1, and 22:1 in milk fat are shown in Supplemental Table S4 (https://doi.org/ 10.3168/jds.2018-15833), and the relative abundances of odd- and branched-chain FA in milk fat are shown in Supplemental Table S5 (https://doi.org/10.3168/jds .2018-15833).

\section{DISCUSSION}

We investigated the effects of dietary FC ratio in grass silage-based diets, and an additional diet containing red clover, on nutrient intake and FA flow at the omasum, milk production, milk FA composition, and MFG size distribution. In previous studies, MFG size distribution was suggested to be partly regulated through dairy cow diet rather than being solely dependent on the daily fat yield (Wiking et al., 2004; Lopez et al., 2008; Argov-Argaman et al., 2014). Addition of DHA-rich microalgae alone or with sieved extruded linseed to corn silage-based diets (Vanbergue et al., 2018), addition of extruded linseed to corn silage and hay-based diets (Lopez et al., 2008), and pasture versus corn silage diet (Couvreur et al., 2007) have been reported to decrease the mean MFG size. In addition, in dairy goats, grazing in Mediterranean brushland resulted in larger MFG compared with clover hay-based diet (Argov-Argaman et al., 2016). Argov-Argaman et al. (2014) investigated the effect of FC ratio in diets consisting of corn silage, oat, and clover hay and observed that a high concentrate content tended to produce smaller MFG compared with contrasting high forage diet. However, it is not well elucidated whether FC ratio in grass silage-based diets or forage type (red clover silage vs. grass silage) affects MFG size distribution. We investigated the changes in MFG size, milk production, and FA composition from feed to milk in different dietary strategies.

In the present study, gross energy, starch, and DM intakes in the high concentrate diet were significantly higher compared with the low concentrate grass silagebased diet. These differences were reflected in higher yields of milk, protein, and lactose in LG compared with HG, which is in agreement with other studies with similar types of dairy cow rations (Argov-Argaman et al., 2014; Ventto et al., 2017). Dietary FC ratio in grass silage-based diets did not affect daily fat yields, although milk yield was the highest in LG, leading to $13 \%$ lower fat concentration in LG compared with HG, which was consistent with previous research with a similar type of 
Table 5. Effects of forage:concentrate ratio in grass silage diets and forage type (red clover silage vs. grass silage) on milk fatty acid composition in lactating cows ${ }^{1}$

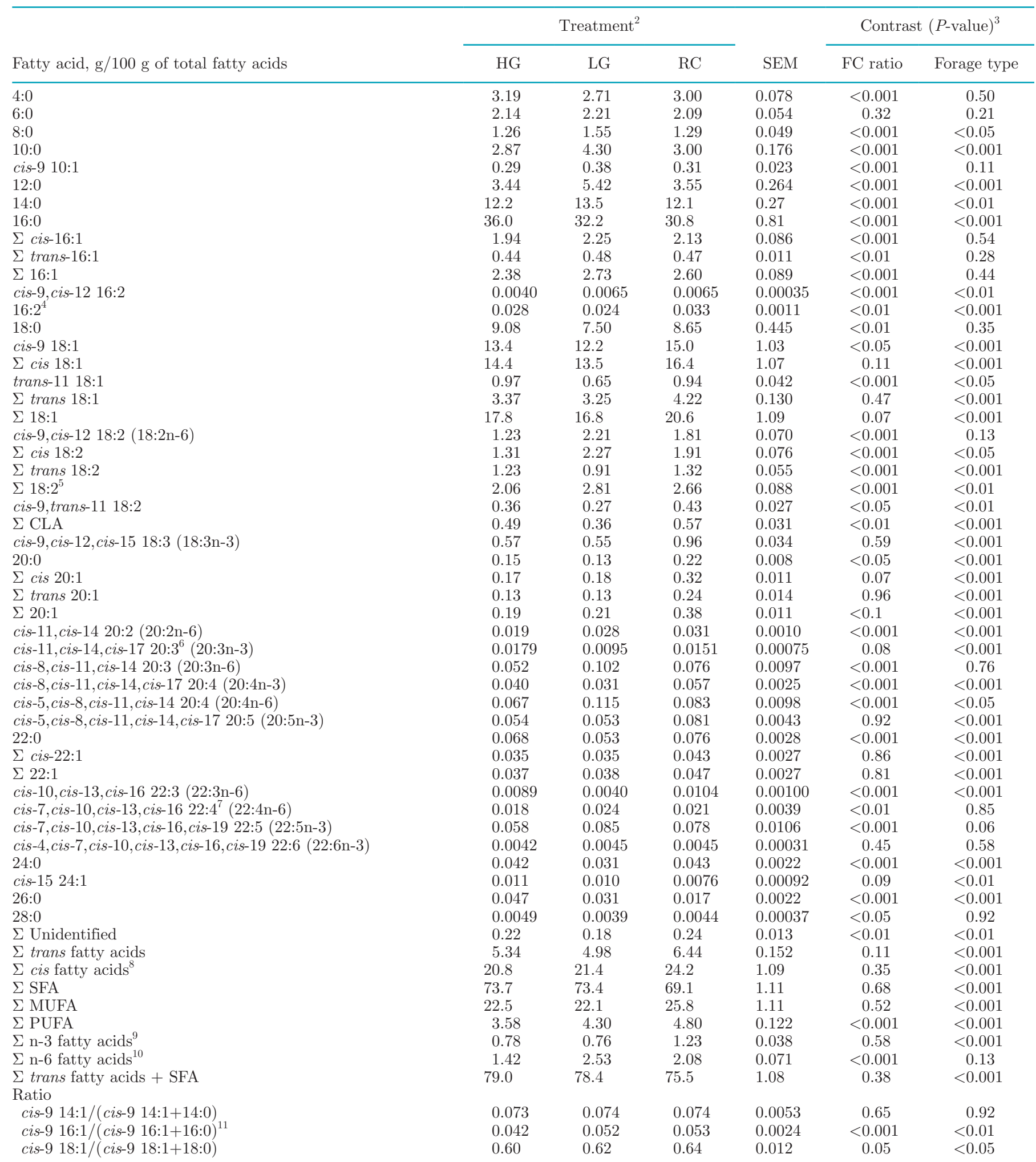


Table 5 (Continued). Effects of forage:concentrate ratio in grass silage diets and forage type (red clover silage vs. grass silage) on milk fatty acid composition in lactating cows

\begin{tabular}{|c|c|c|c|c|c|c|}
\hline Fatty acid, $\mathrm{g} / 100 \mathrm{~g}$ of total fatty acids & \multicolumn{3}{|c|}{ Treatment $^{2}$} & SEM & \multicolumn{2}{|c|}{ Contrast $(P \text {-value })^{3}$} \\
\hline cis-9 trans-11 18:2/(cis-9,trans-11 18:2 + trans-11 18:1) & 0.27 & 0.29 & 0.31 & 0.012 & $<0.01$ & $<0.01$ \\
\hline
\end{tabular}

${ }^{1}$ Values are LSM and pooled SEM, $\mathrm{n}=10$ for each treatment. Values represent the mean over d 30 to 32.

${ }^{2}$ Refers to grass silage diets with forage:concentrate (FC) ratio 70:30 (HG) and 30:70 (LG), and red clover silage-based diet (RC) with FC ratio 50:50.

${ }^{3} \mathrm{FC}$ ratio $=$ forage:concentrate ratio effect (30:70 vs. 70:30 in grass silage diets); forage type $=$ forage effect (red clover silage vs. grass silage).

${ }^{4}$ Indeterminant double bond geometry and position. Co-elutes with cis-7 17:1.

${ }^{5}$ Sum of 18:2 excluding conjugated 18:2 isomers.

${ }^{6}$ Co-elutes with cis-15 22:1.

${ }^{7}$ Co-elutes with 25:0.

${ }^{8} \mathrm{Sum}$ of $c i s$-MUFA and cis-PUFA.

${ }^{9}$ Sum of $22: 6 \mathrm{n}-3,22: 5 \mathrm{n}-3,22: 4 \mathrm{n}-3,20: 5 \mathrm{n}-3,20: 4 \mathrm{n}-3,20: 3 \mathrm{n}-3,18: 3 \mathrm{n}-3$, and cis-12,cis-15 18:2.

${ }^{10}$ Sum of 22:5n-6, 22:4n-6, 22:3n-6, 20:4n-6, 20:2n-6, 18:3n-6, and cis-9, cis-12 18:2.

${ }^{11}$ cis-9 16:1 co-elutes with anteiso 17:0.

treatments (Argov-Argaman et al., 2014). However, RC reduced milk fat content and secretion compared with grass silage-based diets. Previous studies that investigated incremental replacement of grass silage with red clover silage showed no changes in milk fat secretion (Moorby et al., 2009; Halmemies-Beauchet-Filleau et al., 2014), although a reduction in milk fat content was also observed in the study of Moorby et al. (2009).

We measured the MFG size distributions from fresh milk although some other studies have measured either cream (Lopez et al., 2008) or milk with EDTA added to disrupt casein micelles (Couvreur et al., 2006, 2007; Argov-Argaman et al., 2014). Because the size distributions were bimodal and no EDTA was added before MFG measurements, we considered MFG in 2 size classes, $<1 \mu \mathrm{m}$ and $>1 \mu \mathrm{m}$. The size class containing $<1-\mu$ m-diameter globules may partly consist of casein micelles because their diameters vary from 50 to 600 $\mathrm{nm}$ (Fox and Brodkorb, 2008). The presence of caseins disrupted the MFG results for the $<1-\mu \mathrm{m}$ size class in this study, and thus, the results do not represent the entire MFG distribution. In the present study, low concentrate content in grass silage-based diets increased volume-surface diameter of milk fat globules by $+0.15 \mu \mathrm{m}$ and decreased specific surface area by $4 \%$ in the $>1-\mu \mathrm{m}$ size class. In previous studies with corn silage and oat and clover hay, MFG diameter tended to increase by $0.21 \mu \mathrm{m}$ with lower concentrate content (Argov-Argaman et al., 2014), whereas pasture-based diet led to MFG being $0.29 \mu \mathrm{m}$ smaller compared with corn silage-based diet (Couvreur et al., 2006, 2007). However, because the study of Argov-Argaman et al. (2014) was conducted on corn silage and oat and clover hay, comparison with the current results is rather dif- ficult, although they both show reduced MFG size with high-concentrate diets. Furthermore, because of the categorization of MFG into 2 size classes in the present study, the comparison with earlier results is not ideal. The diet containing red clover silage produced globules that were $0.18 \mu \mathrm{m}$ smaller compared with grass silagebased diets in the $>1-\mu \mathrm{m}$ size class. This finding was also reflected in the specific surface area, which was elevated in RC milk compared with grass silage-based diets. However, in the study of Wiking et al. (2010), the MFG diameter was not affected in a comparison of a diet consisting of red clover and ryegrass and a diet based on a mixture of corn and grass silage. Instead, previous studies have reported positive correlation between MFG size and fat yield (Wiking et al., 2004, 2010), fat content, or fat:protein ratio (Couvreur and Hurtaud, 2017). Wiking et al. (2004) hypothesized that when the mammary gland is secreting a high level of fat, the membrane material may become a limiting factor, resulting in larger fat droplets. In this study, although both milk fat yield and MFG size were reduced in RC diet, no correlation between MFG size and milk fat yield was observed (data not shown). The reason for this finding could simply be a high variation between individual cows in general or variation in their individual responses to the diet changes. Logan et al. (2014) also did not observe a relationship between MFG size and milk fat content and yield, which provides support for a cow-to-cow variation in MFG size.

Total FA flow at the omasum exceeded the total FA intakes irrespective of treatment, which can be explained by the activity of rumen microbiota (Ventto et al., 2017). Dietary FC ratio in grass silage-based diets only tended to affect the extent of biohydrogenation of 
Table 6. Effects of forage:concentrate ratio in grass silage diets and forage type (red clover silage vs. grass silage) on milk 18:1, 18:2, and 18:3 fatty acid composition in lactating cows

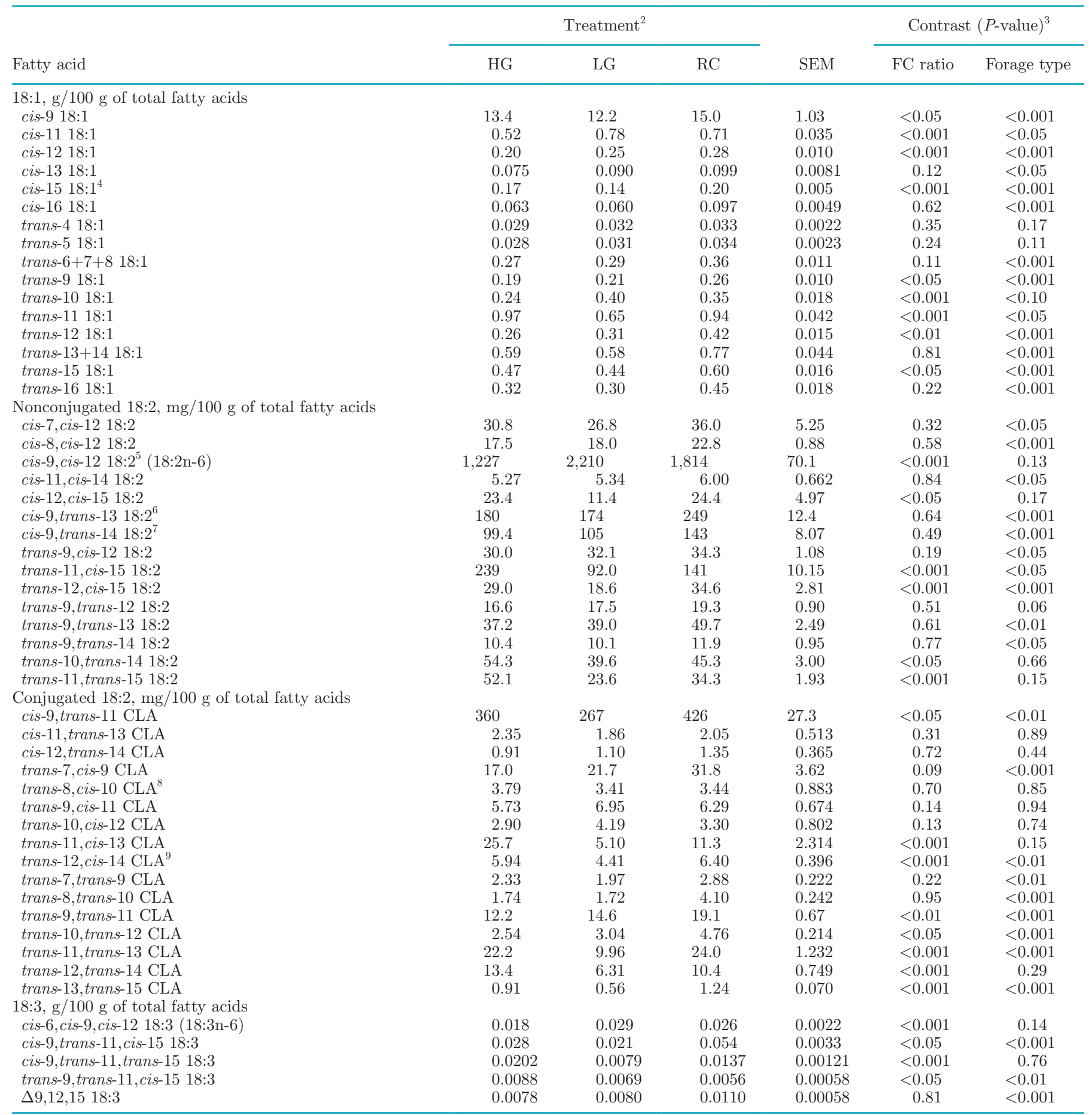

${ }^{1}$ Values are LSM and pooled SEM, $\mathrm{n}=10$ for each treatment. Values represent the mean over d 30 to 32.

${ }^{2}$ Refers to grass silage diets with forage:concentrate (FC) ratio 70:30 (HG) and 30:70 (LG), and red clover silage-based diet (RC) with FC ratio 50:50.

${ }^{3} \mathrm{FC}$ ratio $=$ forage:concentrate ratio effect (30:70 vs. 70:30 in grass silage diets); forage type $=$ forage effect (red clover silage vs. grass silage).

${ }^{4}$ Co-elutes with 19:0

${ }^{5}$ Co-elutes with cis-9,cis-15 18:2 and cis-9 19:1.

${ }^{6}$ Co-elutes with cis-10,trans-14 18:2.

${ }^{7}$ Co-elutes with cis-9,trans-12 18:2.

${ }^{8}$ Co-elutes with cis-7,trans-9 18:2 and cis-8,trans-10 18:2.

${ }^{9}$ Co-elutes with cis-13,trans-15 18:2. 
cis-9 18:1, consistent with earlier reports (Kalscheur et al., 1997; Loor et al., 2004; Ventto et al., 2017), while the flow of cis-9 18:1 was the highest in LG. High concentrate content in LG lowered the apparent biohydrogenation of 18:2n-6 and 18:3n-3 compared with HG, whereas high dietary intake of 18:3n-3 from a high grass diet led to extensive biohydrogenation (92.4\%) in the rumen. In previous studies, 18:2n- 6 has been shown to convert to isomers of $\Delta 9,11$ CLA and $\Delta 10,12$ CLA in the rumen (Honkanen et al., 2012; Ventto et al., 2017). In the present study, a high concentrate content in LG increased the flow of trans-10, cis-12 CLA compared with HG and somewhat favored the formation of trans-10 18:1 in the rumen, increasing it by 2 -fold. This shift from trans-11 to trans-10 intermediates is more pronounced in treatments containing high amounts of concentrate, high starch and low fiber content, and oil supplements, leading to milk fat depression in some cases (Bauman and Griinari, 2003; Ventto et al., 2017). However, in the present study, changes in FA composition in omasal flow and milk fat (indicating milk fat depression) were moderate, and no difference in milk fat yields between HG and LG was observed.

We found that a low FC ratio in diets based on grass silage led to higher PUFA (especially 18:2n-6) content in milk fat, but no effect on the MUFA level. However, RC increased MUFA and PUFA levels in milk fat compared with grass silage-based treatments. Several previous studies have demonstrated that red clover silage increases 18:2n-6 and 18:3n-3 in milk (Vanhatalo et al., 2007; Moorby et al., 2009; Halmemies-BeauchetFilleau et al., 2014), also in direct relation with higher ruminal escape of PUFA (Halmemies-Beauchet-Filleau et al., 2013). Although 18:3n-3 intake in RC was rather moderate in the present study, high ruminal escape led to 1.7-fold increase in milk, which was consistent with previous studies (Dewhurst et al., 2003b; HalmemiesBeauchet-Filleau et al., 2013, 2014). Previous studies have suggested mechanisms including lowered lipolysis as the first rate-limiting step of dietary lipid metabolism in dairy cows, possibly caused by high polyphenol oxidase content in RC (Lee et al., 2007; Buccioni et al., 2012), whereas other studies have not confirmed the role of polyphenol oxidase (Halmemies-BeauchetFilleau et al., 2013). Other suggested mechanisms include changes in rumen passage kinetics, alterations in bacterial diversity, and decreases in feed particle size possibly restricting the binding of ruminal bacteria (Dewhurst et al., 2003a; Huws et al., 2010; Buccioni et al., 2012; Halmemies-Beauchet-Filleau et al., 2013).

Irrespective of treatment, cis-9,trans-11 CLA was the predominant CLA isomer in milk fat; it originates from the biohydrogenation of $18: 2 \mathrm{n}-6$ and $18: 3 \mathrm{n}-3$ by rumen bacteria and the conversion of trans-11 $18: 1$ by $\Delta^{9}$-de- saturase activity in mammary gland tissue (Baumgard et al., 2000; Bauman and Griinari, 2003). The increased MUFA levels in milk fat in RC compared with grass silage-based diets mostly accounted for the high cis-9 18:1 content in milk fat, consistent with earlier studies (Dewhurst et al., 2006; Vanhatalo et al., 2007; Moorby et al., 2009). Seasonal variation in dairy cow diet has been shown to affect unsaturated FA content in MFGM because cis-9 18:1 in milk fat increased during spring feeding based on fresh pasture and decreased in winter feeding based on corn silage (Lopez et al., 2014). In addition, cis-9 18:1 has been identified as a major unsaturated FA accounting for $25 \%$ of total FA in PL of bovine milk powders, whereas total PUFA accounts for more than $9 \%$ of total FA in PL of bovine milk powders (Ali et al., 2017). Smaller MFG contain relatively more PL that are rich in PUFA (Heid and Keenan, 2005; Mesilati-Stahy et al., 2011). The question remains whether higher cis-9 18:1 and total PUFA in milk fat and high omasal flow of PUFA available for absorption in $\mathrm{RC}$ are reflected in MFGM structure.

In conclusion, our findings show that different dietary strategies affect MFG size of raw milk in $>1-\mu \mathrm{m}$ size class, milk production, and overall dairy cow FA metabolism from feed to milk. The FC ratio in grass silage-based diets moderately affected the size of fat globules in the size class $>1 \mu \mathrm{m}$. High concentrate content in grass silage-based diets increased milk yield, but it did not affect fat yield leading to lowered milk fat concentration. A red clover silage-based diet produced smaller fat globules than grass silage-based diets in the same size class and decreased fat yield and fat concentration. However, no correlation between MFG size and milk fat synthesis was observed. Red cloverbased diet led to milk FA composition containing high proportions of MUFA and PUFA, which are beneficial for human health. Milk and dairy products are the major source of SFA in the Western diet, and increasing the proportions of MUFA and PUFA in milk fat could have implications for health without changes being needed in consumer eating habits. Higher MUFA and PUFA levels both at the omasum and in milk fat in RC could reflect the smaller milk fat globules in RC compared with grass silage-based diets. Studies on the effects of grass silage and red clover on MFG size are scarce. Therefore, studies comparing different forage species with same FC ratios or with an incremental replacement of grass silage with red clover would give further insight into the possible relation of milk FA composition and MFG size. To investigate whether the higher PUFA, especially 18:3n-3 content in milk produced with RC is reflected in PL composition, further studies on PL molecular species in RC milk are needed. 


\section{ACKNOWLEDGMENTS}

This research was conducted as part of the Global Network project funded by the Academy of Finland (grant number 281337) through the Joint Programming Initiative on Agriculture, Food Security, and Climate Change (FACCE-JPI) Multi-Partner Call on Agricultural Greenhouse Gas Research initiative. It was supported by Arla Ltd. (Sipoo, Finland); MilkInno project funded by the Finnish Ministry of Agriculture and Forestry, Helsinki, Finland (grant number 2226/03.01.02/2015); and a PhD studentship from the Jenny and Antti Wihuri Foundation (Helsinki, Finland). The authors gratefully acknowledge Valio Ltd. (Helsinki, Finland) for advice and the opportunity to use their Mastersizer 2000 instrument. We thank the staff members of the metabolism unit of Natural Resources Institute Finland (Luke, Jokioinen, Finland) for their contribution to sample collection and care of experimental animals. We greatly appreciate the contributions of Minna Aalto and Tuija Hakala in FA analyses and the Luke laboratory personnel for chemical analyses.

\section{REFERENCES}

Ahvenjärvi, S., A. Vanhatalo, P. Huhtanen, and T. Varvikko. 2000. Determination of reticulo-rumen and whole-stomach digestion in lactating cows by omasal canal or duodenal sampling. Br. J. Nutr. 83:67-77. https://doi.org/10.1017/S0007114500000106.

Ali, A. H., X. Zou, J. Huang, S. M. Abed, G. Tao, Q. Jin, and X. Wang. 2017. Profiling of phospholipids molecular species from different mammalian milk powders by using ultra-performance liquid chromatography-electrospray ionization-quadrupole-time of flightmass spectrometry. J. Food Compos. Anal. 62:143-154. https:// doi.org/10.1016/j.jfca.2017.05.007.

Argov-Argaman, N., O. Haday, T. Glasser, H. Muklada, L. Dvash, R. Mesilati-Stahy, and S. Y. Landau. 2016. Milk fat globule size, phospholipid contents and composition of milk from purebred and Alpine-crossbred Mid-Eastern goats under confinement or grazing condition. Int. Dairy J. 58:2-8. https://doi.org/10.1016/j.idairyj .2015 .12 .003

Argov-Argaman, N., R. Mesilati-Stahy, Y. Magen, and U. Moallem. 2014. Elevated concentrate-to-forage ratio in dairy cow rations is associated with a shift in the diameter of milk fat globules and remodeling of their membranes. J. Dairy Sci. 97:6286-6295. https: //doi.org/10.3168/jds.2014-8174.

Bauman, D. E., and J. M. Griinari. 2003. Nutritional regulation of milk fat synthesis. Annu. Rev. Nutr. 23:203-227. https://doi.org/ 10.1146/annurev.nutr.23.011702.073408.

Baumgard, L. H., B. A. Corl, D. A. Dwyer, A. Saebø, and D. E. Bauman. 2000. Identification of the conjugated linoleic acid isomer that inhibits milk fat synthesis. Am. J. Physiol. Regul. Integr. Comp. Physiol. 278:R179-R184. https://doi.org/10.1152/ajpregu .2000.278.1.R179.

Bayat, A. R., T. Luukkonen, P. Kairenius, H. Leskinen, T. Hurme, S. Ahvenjärvi, and J. Vilkki. 2017. Low and high methane emitting cows hold their ranking over different feeding strategies. J. Dairy Sci. 100(Suppl. 2):220-224.

Buccioni, A., M. Decandia, S. Minieri, G. Molle, and A. Cabiddu. 2012. Lipid metabolism in the rumen: New insights on lipolysis and biohydrogenation with an emphasis on the role of endogenous plant factors. Anim. Feed Sci. Technol. 174:1-25. https://doi.org/ 10.1016/j.anifeedsci.2012.02.009.

Cohen, B., A. Shamay, and N. A. Argaman. 2018. Lipid metabolism in mammary epithelial cells - A comparison of common in vitro models. J. Adv. Dairy Res. 06:1-9. https://doi.org/10.4172/2329 -888 X.1000202.

Couvreur, S., and C. Hurtaud. 2017. Relationships between milks differentiated on native milk fat globule characteristics and fat, protein and calcium compositions. Animal 11:507-518. https://doi .org/10.1017/S1751731116001646.

Couvreur, S., C. Hurtaud, C. Lopez, L. Delaby, and J. L. Peyraud. 2006. The linear relationship between the proportion of fresh grass in the cow diet, milk fatty acid composition, and butter properties. J. Dairy Sci. 89:1956-1969. https://doi.org/10.3168/jds.S0022 -0302(06)72263-9.

Couvreur, S., C. Hurtaud, P. G. Marnet, P. Faverdin, and J. L. Peyraud. 2007. Composition of milk fat from cows selected for milk fat globule size and offered either fresh pasture or a corn silage-based diet. J. Dairy Sci. 90:392-403. https://doi.org/10.3168/jds.S0022 -0302(07)72640-1.

Dewettinck, K., R. Rombaut, N. Thienpont, T. T. Le, K. Messens, and J. Van Camp. 2008. Nutritional and technological aspects of milk fat globule membrane material. Int. Dairy J. 18:436-457. https:// doi.org/10.1016/j.idairyj.2007.10.014.

Dewhurst, R. J., R. T. Evans, N. D. Scollan, J. M. Moorby, R. J. Merry, and R. J. Wilkins. 2003a. Comparison of grass and legume silages for milk production. 2. In vivo and in sacco evaluations of rumen function. J. Dairy Sci. 86:2612-2621. https://doi.org/10 .3168/jds.S0022-0302(03)73856-9.

Dewhurst, R. J., W. J. Fisher, J. K. S. Tweed, and R. J. Wilkins. 2003b. Comparison of grass and legume silages for milk production. 1. Production responses with different levels of concentrate. J. Dairy Sci. 86:2598-2611. https://doi.org/10.3168/jds.S0022 $-0302(03) 73855-7$.

Dewhurst, R. J., K. J. Shingfield, M. R. F. Lee, and N. D. Scollan. 2006. Increasing the concentrations of beneficial polyunsaturated fatty acids in milk produced by dairy cows in high-forage systems. Anim. Feed Sci. Technol. 131:168-206. https://doi.org/10.1016/j anifeedsci.2006.04.016.

Edén, J., P. Dejmek, R. Löfgren, M. Paulsson, and M. Glantz. 2016. Native milk fat globule size and its influence on whipping properties. Int. Dairy J. 61:176-181. https://doi.org/10.1016/j.idairyj .2016.06.004.

European Council. 1986. Council Directive of 24 November 1986 on the approximation of laws, regulations and administrative provisions of the Member States regarding the protection of animals used for experimental and other scientific purposes (86/609/EEC). Off. J. Eur. Communities 29:1-28.

Fox, P. F., and A. Brodkorb. 2008. The casein micelle: Historical aspects, current concepts and significance. Int. Dairy J. 18:677-684. https://doi.org/10.1016/j.idairyj.2008.03.002.

Garcia, C., C. Antona, B. Robert, C. Lopez, and M. Armand. 2014 The size and interfacial composition of milk fat globules are key factors controlling triglycerides bioavailability in simulated human gastro-duodenal digestion. Food Hydrocoll. 35:494-504. https:// doi.org/10.1016/j.foodhyd.2013.07.005.

Halmemies-Beauchet-Filleau, A., T. Kokkonen, A.-M. Lampi, V. Toivonen, K. J. Shingfield, and A. Vanhatalo. 2011. Effect of plant oils and camelina expeller on milk fatty acid composition in lactating cows fed diets based on red clover silage. J. Dairy Sci. 94:44134430. https://doi.org/10.3168/jds.2010-3885.

Halmemies-Beauchet-Filleau, A., A. Vanhatalo, V. Toivonen, T. Heikkilä, and M. R. F. Lee. 2014. Effect of replacing grass silage with red clover silage on nutrient digestion, nitrogen metabolism, and milk fat composition in lactating cows fed diets containing a 60:40 forage-to-concentrate ratio. J. Dairy Sci. 97:3761-3776. https:// doi.org/10.3168/jds.2013-7358.

Halmemies-Beauchet-Filleau, A., A. Vanhatalo, V. Toivonen, T. Heikkilä, M. R. F. Lee, and K. J. Shingfield. 2013. Effect of replacing grass silage with red clover silage on ruminal lipid metabolism in lactating cows fed diets containing a 60:40 forage-to-concentrate 
ratio. J. Dairy Sci. 96:5882-5900. https://doi.org/10.3168/jds 2013-6872.

Heid, H. W., and T. W. Keenan. 2005. Intracellular origin and secretion of milk fat globules. Eur. J. Cell Biol. 84:245-258. https://doi .org/10.1016/j.ejcb.2004.12.002

Honkanen, A. M., J. M. Griinari, A. Vanhatalo, S. Ahvenjärvi, V. Toivonen, and K. J. Shingfield. 2012. Characterization of the disappearance and formation of biohydrogenation intermediates during incubations of linoleic acid with rumen fluid in vitro. J. Dairy Sci. 95:1376-1394. https://doi.org/10.3168/jds.2011-4390.

Huws, S. A., M. R. F. Lee, S. M. Muetzel, M. B. Scott, R. J. Wallace, and N. D. Scollan. 2010. Forage type and fish oil cause shifts in rumen bacterial diversity. FEMS Microbiol. Ecol. 73:396-407. https: //doi.org/10.1111/j.1574-6941.2010.00892.x.

Jiménez-Flores, R., and G. Brisson. 2008. The milk fat globule membrane as an ingredient: Why, how, when? Dairy Sci. Technol. 88:5-18.

Kalscheur, K. F., B. B. Teter, L. S. Piperova, and R. A. Erdman 1997. Effect of dietary forage concentration and buffer addition on duodenal flow of trans-C18:1 fatty acids and milk fat production in dairy cows. J. Dairy Sci. 80:2104-2114. https://doi.org/10.3168/ jds.S0022-0302(97)76156-3.

Lee, M. R., L. J. Parfitt, N. D. Scollan, and F. R. Minchin. 2007. Lipolysis in red clover with different polyphenol oxidase activities in the presence and absence of rumen fluid. J. Sci. Food Agric. 87:1308-1314. https://doi.org/10.1002/jsfa.2849.

Logan, A., M. Auldist, J. Greenwood, and L. Day. 2014. Natural variation of bovine milk fat globule size within a herd. J. Dairy Sci. 97:4072-4082. https://doi.org/10.3168/jds.2014-8010.

Logan, A., M. Xu, L. Day, T. Singh, S. C. Moore, M. Mazzonetto, and M. A. Augustin. 2017. Milk fat globule size affects Cheddar cheese properties. Int. Dairy J. 70:46-54. https://doi.org/10.1016/ j.idairyj.2016.11.003

Loor, J. J., K. Ueda, A. Ferlay, Y. Chilliard, and M. Doreau. 2004. Biohydrogenation, duodenal flow, and intestinal digestibility of trans fatty acids and conjugated linoleic acids in response to dietary forage:concentrate ratio and linseed oil in dairy cows. J. Dairy Sci. 87:2472-2485. https://doi.org/10.3168/jds.S0022-0302(04)73372 $-\mathrm{X}$.

Lopez, C., V. Briard-Bion, and O. Ménard. 2014. Polar lipids, sphingomyelin and long-chain unsaturated fatty acids from the milk fat globule membrane are increased in milks produced by cows fed fresh pasture based diet during spring. Food Res. Int. 58:59-68. https://doi.org/10.1016/j.foodres.2014.01.049.

Lopez, C., V. Briard-Bion, O. Menard, F. Rousseau, P. Pradel, and J. M. Besle. 2008. Phospholipid, sphingolipid, and fatty acid compositions of the milk fat globule membrane are modified by diet. J. Agric. Food Chem. 56:5226-5236. https://doi.org/10.1021/ jf7036104.

Lu, J., N. Argov-Argaman, J. Anggrek, S. Boeren, T. van Hooijdonk, J. Vervoort, and K. A. Hettinga. 2016. The protein and lipid composition of the membrane of milk fat globules depends on their size. J. Dairy Sci. 99:4726-4738. https://doi.org/10.3168/jds.2015 -10375 .

Masedunskas, A., Y. Chen, R. Stussman, R. Weigert, and I. H. Mather. 2017. Kinetics of milk lipid droplet transport, growth, and secretion revealed by intravital imaging: Lipid droplet release is intermittently stimulated by oxytocin. Mol. Biol. Cell 28:935-946. https://doi.org/10.1091/mbc.E16-11-0776.

Mesilati-Stahy, R., K. Mida, and N. Argov-Argaman. 2011. Size-dependent lipid content of bovine milk fat globule and membrane phospholipids. J. Agric. Food Chem. 59:7427-7435. https://doi .org/10.1021/jf201373j.

Mesilati-Stahy, R., U. Moallem, Y. Magen, and N. Argov-Argaman. 2015. Altered concentrate to forage ratio in cows ration enhanced bioproduction of specific size subpopulation of milk fat globules. Food Chem. 179:199-205. https://doi.org/10.1016/j.foodchem 2015.01.138.

Moorby, J. M., M. R. F. Lee, D. R. Davies, E. J. Kim, G. R. Nute, N. M. Ellis, and N. D. Scollan. 2009. Assessment of dietary ratios of red clover and grass silages on milk production and milk quality in dairy cows. J. Dairy Sci. 92:1148-1160. https://doi.org/10.3168/ jds.2008-1771.

Shingfield, K. J., S. Ahvenjärvi, V. Toivonen, A. Ärölä, K. V. V. Nurmela, P. Huhtanen, and J. M. Griinari. 2003. Effect of dietary fish oil on biohydrogenation of fatty acids and milk fatty acid content in cows. Anim. Sci. 77:165-179.

Shingfield, K. J., S. Jaakkola, and P. Huhtanen. 2002. Effect of forage conservation method, concentrate level and propylene glycol on diet digestibility, rumen fermentation, blood metabolite concentrations and nutrient utilisation of dairy cows. Anim. Feed Sci. Technol. 97:1-21. https://doi.org/10.1016/S0377-8401(02)00006-8.

Singh, H., and S. Gallier. 2017. Nature's complex emulsion: The fat globules of milk. Food Hydrocoll. 68:81-89. https://doi.org/10 .1016/j.foodhyd.2016.10.011.

Spitsberg, V. L. 2005. Invited review: Bovine milk fat globule membrane as a potential nutraceutical. J. Dairy Sci. 88:2289-2294 https://doi.org/10.3168/jds.S0022-0302(05)72906-4.

Tapio, I., A. R. Bayat, S. Ahvenjärvi, T. Luukkonen, and J. Vilkki. 2018. The overall structure of rumen bacterial communities significantly differentiates animals by diet but not by their methane emission phenotype. Adv. Anim. Biosci. 352. https://doi.org/10 $.1017 /$ S2040470013000204.

Timby, N., E. Domellöf, O. Hernell, B. Lönnerdal, and M. Domellöf. 2014. Neurodevelopment, nutrition, and growth until 12 mo of age in infants fed a low-energy, low-protein formula supplemented with bovine milk fat globule membranes: A randomized controlled trial. Am. J. Clin. Nutr. 99:860-868. https://doi.org/10.3945/ajcn .113 .064295

Vanbergue, E., J. L. Peyraud, and C. Hurtaud. 2018. Effects of new n-3 fatty acid sources on milk fatty acid profile and milk fat properties in dairy cows. J. Dairy Res. 85:265-272. https://doi.org/10 $.1017 /$ S0022029918000390.

Vanhatalo, A., K. Kuoppala, V. Toivonen, and K. J. Shingfield. 2007. Effects of forage species and stage of maturity on bovine milk fatty acid composition. Eur. J. Lipid Sci. Technol. 109:856-867. https:/ /doi.org/10.1002/ejlt.200700023.

Ventto, L., H. Leskinen, P. Kairenius, T. Stefański, A. R. Bayat, J. Vilkki, and K. J. Shingfield. 2017. Diet-induced milk fat depression is associated with alterations in ruminal biohydrogenation pathways and formation of novel fatty acid intermediates in lactating cows. Br. J. Nutr. 117:364-376. https://doi.org/10.1017/ S0007114517000010.

Wiking, L., J. Stagsted, L. Björck, and J. H. Nielsen. 2004. Milk fat globule size is affected by fat production in dairy cows. Int. Dairy J. 14:909-913. https://doi.org/10.1016/j.idairyj.2004.03.005.

Wiking, L., P. K. Theil, J. H. Nielsen, and M. T. Sørensen. 2010. Effect of grazing fresh legumes or feeding silage on fatty acids and enzymes involved in the synthesis of milk fat in dairy cows. J. Dairy Res. 77:337-342. https://doi.org/10.1017/S002202991000021X. 